\title{
Utilization of Benefits of Developmental Programmes by Agricultural Labour Households in Karnataka-an Institutional Economic Analysis
}

\author{
B. N. Venu*, K. B. Umesh, Jagannath Olekar and B. V. Chinnappa Reddy
}

Dept. of Agricultural Economics, University of Agricultural Sciences, Bengaluru, Karnataka (560 065), India

\section{Corresponding Author}

B. N. Venu

e-mail: gowdaregalia@gmail.com

\author{
Article History \\ Article ID: AR1678 \\ Received in $16^{\text {th }}$ September, 2016 \\ Received in revised form $16^{\text {th }}$ November, 2017 \\ Accepted in final form $29^{\text {th }}$ November, 2017
}

\begin{abstract}
Good governance is crucial for inclusive growth. In this study access to benefits and spread of the benefits from various Government programmes is compared among migration and non-migration labours in irrigated and rainfed regions of Karnataka. Generally the developmental programs are more focused towards welfare of the intended labour households. All the labour households of irrigated situation were getting benefits under BPL card legally. In rainfed situation, on an average $95 \%$ of labour households benefited through BPL card. Due to low or no participation in Co-operatives by rainfed labour households the Yashasvini card benefit was less compare to irrigated situation. Due to lower level of income and illiteracy of the labour households, they were not able to send their children to study in private schools. Therefore most of the labour households availed benefit under programmes like Mid-Day Meal Scheme and Kaliyuva Makkalige Bicycle schemes. Average annual benefit received by the agricultural labour households through various programmes was high in irrigated $(₹ 19,550)$ compared to rainfed situation ( $₹ 19,391)$. All the labour households in both the situations incurred highest transaction cost while getting benefit from the rural housing schemes. The transaction cost for getting benefit was zero for the programmes like Mid-Day Meal and Kaliyuva Makkalige Bicycle which was free of any rent.
\end{abstract}

Keywords: Annual benefit, transaction cost, information cost, opportunity cost, rent seeking

\section{Introduction}

Good governance is crucial for inclusive growth. Karnataka has been a role model in designing and implementing several types of innovative Government programmes for alleviation of poverty in rural areas. This study focuses on estimating annual benefit received by agricultural labours from different developmental programmes implemented by both central and state government in Karnataka. There are many successive Governments chalk out programmes devoting planned funds for the welfare of the people (Maheshwari and Gangwar, 2011, Prabakara et al., 2011). Considering the modern economic growth parameters and the perception of the development practitioners, different programmes were shaped at different times of economic development (Bhuvaneshwari, 2008; Devi et al., 2011). During the green revolution, food production was the major goal by increasing the productivity of the land. During that time, subsidies were provided for the fertilizers and other agro chemicals through different programmes (Harisha et al., 2011; Upadhyay and Palanivel, 2011). In early 1980's India achieved self sufficiency in food and launched the food distribution programme through PDS.

The Government of Karnataka has been launching different types of programmes for the benefit of farmers and other citizens. The details of all programmes are not available at any particular place. Hence efforts have been made to collect the details of the programmes, in the process it is likely that some of the governmental programmes may not have been listed. While the number of programmes and the diversity are crucial as each programme is theoretically unique, the governance of the programme is the most crucial aspect of the development (Merin, 2012; Shyam et al., 2013) Without good governance mere launching of programmes and schemes has limited application in the development economies. Hence this study is an attempt to analyze the reach of governmental programmes for agricultural labours.

Transaction costs (TC) are costs involved in making an economic exchange. In the context of developmental programs, TCs are those involved in participating and deriving benefit from development programs. The three components of the TCs are (1) Search and information costs incurred in finding about the different developmental programs which have different benefit flows; (2) Bargaining costs are the contractual costs involved in documentation necessary to obtain the benefits; and the (3) Policing and enforcement costs 
are the costs of confirming and obtaining the benefit from developmental programs making sure that the Government machinery sticks to the rules and provides services according to the stipulations of the beneficial program.

The Transaction costs include rents paid to official machinery/ middlemen while obtaining documents and the benefits from the program. These are under the ambit of institutional economics where due to Bounded rationality, rationality of farmers is limited by the information they have, the cognitive limitations of their mind, and the limited time they have to make decisions. Transaction costs included the (a) value of the time spent in preparing documents and applying for the program, (b) expenditure involved in documents to be produced, (c) rents paid towards sanction of the benefit.

\section{Materials and Methods}

The present study was taken up in Mandya and Malavalli taluks of Mandya district (irrigated situation) and Bijapur and Indi taluks of Bijapur district of India (rainfed situation) during 2014. Migration and non-migration labour households were classified based on migration of any number of members from their family, but not the whole family. From each taluk, 15 migration and 15 non-migration labour households were selected randomly. Thus, the total sample for the study was 120 agricultural labour households.

The data were collected from primary and secondary sources. Personal interview method was followed to collect the primary data using pre-tested schedule. For achieving the objectives of the study, data were analyzed using tabular presentation; averages, proportions and amortization were specially employed to estimate the utilization of benefits from governmental programmes.

\subsection{Amortization of benefits availed from developmental programmes}

Some of the developmental programmes like Indira Awas Yojana, Bicycle for children studying $8^{\text {th }}$ standard etc... the benefits are extended over time. Thus, the benefit derived by such beneficiaries is amortized using the formula.

$\mathrm{A}=\mathrm{P} \frac{(1+\mathrm{r})^{\mathrm{n}}}{\mathrm{r}(1+\mathrm{r})^{\mathrm{n}}-1}$

Where,

$A=$ Amortized benefit year ${ }^{-1}$ from particular developmental programme.

$\mathrm{P}=$ Total initial benefit received by the beneficiary farmer. $r=$ interest rate period ${ }^{-1}, r$ is taken as $2 \%$ since the benefits are from social welfare schemes over a long period of time $n=$ total number of years of benefit flow, $n$ is taken as the total number of years for each program (for eg. Indira Awasa Yojana house construction for rural poor's is taken for 20 years, Bicycle scheme for school going children for 10 years).

\subsection{Transaction cost}

Transaction costs refer to the costs incurred by the labour in receiving the benefit and they include the cost borne by labour in submitting the application, necessary documents to be produced along with the application for the Government programme, opportunity cost of the time spent by labour in availing the benefit, calculated in terms of sacrificed labor time and the amount of rents paid to different officials, middlemen and local leaders to avail the benefit. In this study transaction cost of labours was defined as the opportunity foregone by the labours measured in terms of wage rate day ${ }^{-1}$ including the managerial cost as followed by the CACP (commission for agriculture costs and prices) while estimating the cost of the farmers involved in farm management. Wage rate is taken as ₹ 175 day $^{-1}$ prevailing in the study area and $10 \%$ towards the managerial cost and other transaction costs paid out by farmer are rents (bribes) to the officials, middlemen, local leaders and other costs involved in applying for Government programme like, documents to be given along with application form. Information costs include time spent by the farmers in availing information regarding Government programmes subsidy ${ }^{-1}$ scheme, visits to line Department to get information.

\section{Results and Discussion}

\subsection{Extent of utilization of benefits of different programmes} by labour households

\subsubsection{No. of agricultural labour households availing benefit}

\subsubsection{Irrigated situation}

Number of labour households availing benefit through various developmental programmes under irrigated situation is presented in Table 1.

All the labour households were getting benefit of ration card.

Table 1: No. of agricultural labour households getting benefit from developmental programmes in irrigated situation

\begin{tabular}{llcc}
\hline SI. & Name of the program / & \multicolumn{2}{c}{ Irrigated } \\
\cline { 3 - 4 } & & $\begin{array}{c}\text { Migration } \\
(\mathrm{n}=30)\end{array}$ & $\begin{array}{c}\text { Non migration } \\
(\mathrm{n}=30)\end{array}$ \\
\hline 1. & Ration card & $30(100)$ & $30(100)$ \\
2. & Mid-Day Meal scheme & $8(27)$ & $8(27)$ \\
3. & Yashasvini card & $3(10)$ & $2(7)$ \\
4. & Kaliyuva Makkalige & $12(40)$ & $15(50)$ \\
& bicycle & & \\
5. & Old age pension scheme & $7(23)$ & $11(37)$ \\
6. & Namma Mane & $2(7)$ & $0(0)$ \\
7. & Bhagya laxmi yojana & $2(7)$ & $3(10)$ \\
8. & Bhagyajyothi & $16(53)$ & $14(47)$ \\
9. & Indira Awas Yojana & $5(17)$ & $3(10)$ \\
10. & Bhoochetana Scheme & $4(13)$ & $5(17)$ \\
11. & Ambedkar devboard & $5(17)$ & $5(17)$ \\
& scheme & & \\
12. & Nirmala Grama & $14(47)$ & $9(30)$ \\
13. & Widow scheme & $2(7)$ & $5(17)$ \\
14. & MGNREGA & $14(47)$ & $9(30)$ \\
\hline
\end{tabular}

Figures in parentheses represent percentage to total 
In case of migration labour households, $53 \%$ and $47 \%$ of households availing benefit from Bhagyajyothi, Nirmala Grama Scheme and in non-migration $47 \%$ and $30 \%$, respectively. Widow scheme and Bhagya Lakshmi Scheme benefit was availed only for $7 \%$ in migration and $10 \%$ in non-migration households. The number of households availing benefit under Mid-Day Meal (27\%) and Kaliyuva Makkalige Bicycle (50\%) was more in non-migration. In MGNREGA scheme, $47 \%$ of migration and $30 \%$ of non-migration households was benefited. $7 \%$ of the non-migration households possess Yashasvini card and $10 \%$ of migration household are having this facility.

\subsubsection{Rainfed situation}

In rainfed situation, both migration and non-migration respondents were not getting any sort of benefit from programs like MGNREGA, Widow Scheme, Nirmala Grama, Bhoochethana and Bhagyalaxmi Yojana (Table 2). Ninety $7 \%$ of migration and $93 \%$ non-migration labour households were getting benefit from ration card. In case of Bhagyajyothi scheme, $33 \%$ of migration and $20 \%$ of non-migration labour households availing benefit. Migration households availed benefit under Mid-Day Meal (40\%) and Kaliyuva Makkalige Bicycle (37\%) and non-migration labour households benefited Mid-Day Meal (20\%) and Kaliyuva Makkalige Bicycle (40\%). In old age pension scheme, $13 \%$ of migration and $23 \%$ of nonmigration households getting benefit.

\begin{tabular}{|c|c|c|c|}
\hline \multirow{2}{*}{$\begin{array}{l}\text { Sl. } \\
\text { No. }\end{array}$} & \multirow{2}{*}{$\begin{array}{l}\text { Name of the program/ } \\
\text { scheme }\end{array}$} & \multicolumn{2}{|c|}{ Rainfed } \\
\hline & & $\begin{array}{l}\text { Migration } \\
(n=30)\end{array}$ & $\begin{array}{c}\text { Non migration } \\
(\mathrm{n}=30)\end{array}$ \\
\hline 1. & Ration card & $29(97)$ & $28(93)$ \\
\hline 2. & Mid-Day Meal scheme & $12(40)$ & $6(20)$ \\
\hline 3. & Yashasvini card & $0(0)$ & $1(3)$ \\
\hline 4. & $\begin{array}{l}\text { Kaliyuva Makkalige } \\
\text { bicycle }\end{array}$ & $11(37)$ & $12(40)$ \\
\hline 5. & Old age pension scheme & $4(13)$ & $7(23)$ \\
\hline 6. & Namma Mane & $4(13)$ & $1(3)$ \\
\hline 7. & Bhagya laxmi yojana & $0(0)$ & $0(0)$ \\
\hline 8. & Bhagyajyothi & $10(33)$ & $6(20)$ \\
\hline 9. & Indira Awas Yojana & $3(10)$ & $3(10)$ \\
\hline 10. & Bhoochetana scheme & $0(0)$ & $0(0)$ \\
\hline 11. & $\begin{array}{l}\text { Ambedkar devboard } \\
\text { scheme }\end{array}$ & $3(10)$ & $0(0)$ \\
\hline 12. & Nirmala Grama & $0(0)$ & $0(0)$ \\
\hline 13. & Widow scheme & $0(0)$ & $0(0)$ \\
\hline 14. & MGNREGA & $0(0)$ & $0(0)$ \\
\hline
\end{tabular}

Figures in parentheses represent percentage to total
Generally the developmental programs are more focused towards welfare of the intended labour households. All the labour households of irrigated situation were getting benefits under BPL card legally. In rainfed situation, on an average $95 \%$ of labour households benefited through BPL card and only $5 \%$ of labour households not getting benefit.

Due to low or no participation in Co-operatives by rainfed labour households the Yashasvini card benefit was less compare to irrigated situation. Due to lower level of income and illiteracy of the labour households, they were not able to send their children to study in private schools. Therefore most of the labour households availed benefit under programmes like Mid-Day Meal Scheme and Kaliyuva Makkalige Bicycle schemes.

\subsubsection{Benefit to labour households from developmental programmes}

Agricultural labour households availing benefits through various developmental programmes are presented in Table 3 for irrigated and rainfed situation.

\subsubsection{Irrigated situation}

In irrigated situation, non-migrant labour households benefited on an average ₹ 19,729 by participating in 14 developmental programmes of which maximum benefit was from Ration card (27.42\%) followed by widow scheme (14.19\%) and Ambedkar devboard schemes (13.56\%). In migrant labour households, a beneficiary family derived on an average ₹ 19,371 of which maximum benefit was from Ration Card $(26.51 \%)$, followed by widow scheme $(12.39 \%)$ and Old Age Pension Scheme (11.05\%).

\subsubsection{Rainfed situation}

In rainfed situation, migrant labour households derived maximum benefit $₹ 21,100$ by participating in 10 developmental programmes of which major benefit was from Ration card (25.36\%), followed by Namma Mane (15.94\%) and Indira Awas Yojana (15.45\%). In non-migrant labour households, the average benefit from the programmes was ₹ 17,682 by participating in 11 developmental programmes. The mojor portion of benefit was from Ration card (28.22\%), followed by Namma Mane (18.12\%) and Indira Awas Yojana (14.72\%). In both the situations, the major portion benefit was from Ration card and housing schemes like Namma Mane and Indira Awas Yojana. The labour households in irrigated situation were relatively more benefited compared to rainfed labour households due to lack of awareness and participation.

\subsection{Transaction cost incurred by labour households in availing benefit}

Transaction Costs (TCS) are involved in deriving benefit from developmental programs. Cost involves information costs, contractual costs and enforcement costs while deriving benefit from developmental programs. Higher transaction costs deter active participation in developmental programmes and thus reduce the benefit flows. 


\begin{tabular}{|c|c|c|c|c|c|c|c|}
\hline \multirow{2}{*}{$\begin{array}{l}\text { Sl. } \\
\text { No. }\end{array}$} & \multirow{2}{*}{$\begin{array}{l}\text { Name of the pro- } \\
\text { gram/scheme }\end{array}$} & \multicolumn{3}{|c|}{ Irrigated (Mandya) } & \multicolumn{3}{|c|}{ Rainfed (Bijapur) } \\
\hline & & Migration & Non Migration & Overall & Migration & Non Migration & Overall \\
\hline 1. & Ration card & $5136(26.51)$ & $5410(27.42)$ & $5273(26.97)$ & $5352(25.36)$ & $5593(31.63)$ & $5473(28.22)$ \\
\hline 2. & $\begin{array}{l}\text { Mid-Day Meal } \\
\text { scheme }\end{array}$ & $768(3.96)$ & 768 (3.89) & $768(3.93)$ & $768(3.64)$ & $768(4.34)$ & $768(3.96)$ \\
\hline 3. & Yashasvini card & $400(2.06)$ & $333(1.69)$ & $367(1.88)$ & $0(0.00)$ & 527 (2.98) & $263(1.36)$ \\
\hline 4. & $\begin{array}{l}\text { Kaliyuva Makkalige } \\
\text { bicycle }\end{array}$ & $\begin{array}{c}2350 \\
{[259](1.34)}\end{array}$ & $\begin{array}{c}2350 \\
{[259](1.31)}\end{array}$ & $\begin{array}{c}2350 \\
{[259](1.32)}\end{array}$ & $\begin{array}{c}2960 \\
{[297](1.41)}\end{array}$ & $\begin{array}{c}2960 \\
{[297](1.68)}\end{array}$ & $\begin{array}{c}2960 \\
{[297](1.53)}\end{array}$ \\
\hline 5. & $\begin{array}{l}\text { Old age pension } \\
\text { scheme }\end{array}$ & $2140(11.05)$ & $2280(11.56)$ & $2210(11.30)$ & $2200(10.43)$ & $2800(15.84)$ & 2500 (12.89) \\
\hline 6. & Namma Mane & $\begin{array}{c}22500 \\
{[1376](7.10)}\end{array}$ & $\begin{array}{c}0 \\
{[0](0.00)}\end{array}$ & $\begin{array}{c}11250 \\
{[688](3.52)}\end{array}$ & $\begin{array}{c}55000 \\
{[3363](15.94)}\end{array}$ & $\begin{array}{c}60000 \\
{[3669](20.75)}\end{array}$ & $\begin{array}{c}57500 \\
{[3516](18.13)}\end{array}$ \\
\hline 7. & Bhagya laxmi yojana & $600(3.10)$ & $600(3.04)$ & $600(3.07)$ & $600(2.84)$ & 600 (3.39) & $600(3.09)$ \\
\hline 8. & Bhagyajyothi & $982(5.07)$ & $982(4.98)$ & $982(5.02)$ & $982(4.65)$ & $982(5.55)$ & $982(5.06)$ \\
\hline 9. & Indira Awas Yojana & $\begin{array}{c}26250 \\
{[1605](8.29)}\end{array}$ & $\begin{array}{c}23333 \\
{[1426](7.23)}\end{array}$ & $\begin{array}{c}24791 \\
{[1516](7.75)}\end{array}$ & $\begin{array}{c}53333 \\
{[3261](15.45)}\end{array}$ & $\begin{array}{c}40000 \\
{[2446](13.83)}\end{array}$ & $\begin{array}{c}46666 \\
{[2854(14.72)}\end{array}$ \\
\hline 10. & $\begin{array}{l}\text { Bhoochetana } \\
\text { Scheme }\end{array}$ & $625(3.23)$ & $400(2.03)$ & $513(2.62)$ & $0(0.00)$ & $0(0.00)$ & $0(0.00)$ \\
\hline 11. & $\begin{array}{l}\text { Ambedkar } \\
\text { devboard scheme }\end{array}$ & $\begin{array}{c}27500 \\
{[1681](8.68)}\end{array}$ & $\begin{array}{c}43750 \\
{[2675](13.56)}\end{array}$ & $\begin{array}{c}35625 \\
{[2178(11.14)}\end{array}$ & $\begin{array}{c}66666 \\
{[2077](9.84)}\end{array}$ & $\begin{array}{c}0 \\
{[0](0.00)}\end{array}$ & $\begin{array}{c}33333 \\
{[1039](5.36)}\end{array}$ \\
\hline 12. & Nirmala Grama & $\begin{array}{c}4393 \\
{[489](2.52)}\end{array}$ & $\begin{array}{c}5000 \\
{[556](2.82)}\end{array}$ & $\begin{array}{c}4696 \\
{[522](2.67)}\end{array}$ & $\begin{array}{c}0 \\
{[0](0.00)}\end{array}$ & $\begin{array}{c}0 \\
{[0]} \\
(0.00)\end{array}$ & $\begin{array}{c}0 \\
{[0](0.00)}\end{array}$ \\
\hline 13. & Widow scheme & $2400(12.39)$ & $2800(14.19)$ & $2600(13.30)$ & $2200(10.43)$ & $0(0.00)$ & $1100(5.67)$ \\
\hline 14. & MGNREGA & $910(4.70)$ & $1240(6.29)$ & $1075(5.50)$ & $0(0.00)$ & $0(0.00)$ & $0(0.00)$ \\
\hline & Average & $19371(100)$ & $19729(100)$ & 19550 (100) & $21100(100)$ & $17682(100)$ & $19391(100)$ \\
\hline
\end{tabular}

Figures in parentheses () represent percentage to total; Figures in [ ] represent amortized annual benefit in rupees edit@epw.in

Major part of transaction cost is the time spent in availing benefit from developmental programmes which include opportunity cost of labour, cost of preparation of documents required to obtain the program benefits and the rents paid out to officials and middlemen.

\subsubsection{Irrigated situation}

The transaction cost incurred by the irrigated labour households is presented in Table 4 and 5 . In migration labour households, highest transaction cost of ₹ 3,912 family ${ }^{-1}$ was incurred while getting benefit from the Indira Awas Yojana (rural housing scheme) of which $56.24 \%$ was the documentation, $42.87 \%$ was the rent paid and remaining $15.64 \%$ was the opportunity cost of labour. Similarly, ₹ 3,850 family $^{-1}$ was incurred while applying for namma mane (rural housing scheme) of which $12.99 \%$ was the rent paid, $22.08 \%$ was the opportunity cost of labour and $64.94 \%$ was documentation cost.

For the old age pension program, labour households incurred transaction cost of ₹ 2,836 of which $64.23 \%$ was opportunity cost of labor, $9.07 \%$ was the rent and $26.70 \%$ was documentation cost. On an average, highest time spent on availing the old age pension benefit was 10.71 man days. In case, of non-migration labour households, highest transaction cost of ₹ 4,940 family $^{-1}$ was incurred while getting benefit from the Ambedkar Dev board Scheme (rural housing scheme) of which $40.33 \%$ was the documentation, $21.35 \%$ was the rent paid and remaining $38.32 \%$ was the opportunity cost of labour ( 7 man days). Similarly, ₹ 1,790 family $^{-1}$ was incurred while applying for Indira Awas Yojana (rural housing scheme) of which $27.93 \%$ was the rent paid, $34.82 \%$ was the opportunity cost of labour (3.60 man days) and $37.24 \%$ was documentation cost.

For the old age pension program, labour households incurred transaction cost of ₹ 1,241 of which $31.14 \%$ was opportunity cost of labor, $19.78 \%$ was the rent and $49.08 \%$ was documentation cost.

The transaction cost for getting benefit was zero in case of programmes like Mid-Day Meal and Kaliyuva Makkalige Bicycle which is free of any rent. Opportunity cost was worked out on the basis of the next best alternative available to the person (i.e. daily wage rate of work @ ₹ 170 man $^{-1}$ day) instead of spending time on availing benefit.

\subsubsection{Rainfed situation}

The transaction cost incurred by the rainfed labour households is presented in Table 6 and 7. In migration labour households, 
Table 4: Transaction costs incurred by migration agricultural labour households in availing benefit of developmental programs in irrigated situation

\begin{tabular}{|c|c|c|c|c|c|c|}
\hline \multirow{2}{*}{$\begin{array}{l}\text { Sl. } \\
\text { No. }\end{array}$} & \multirow{2}{*}{$\begin{array}{l}\text { Name of the program/ } \\
\text { scheme }\end{array}$} & \multirow[t]{2}{*}{ TSAB } & \multicolumn{3}{|c|}{ Transaction cost } & \multirow{2}{*}{$\begin{array}{l}\text { Total transaction cost } \\
\text { program }^{-1}(₹)\end{array}$} \\
\hline & & & OCLAB (₹) & EMODPAC (₹) & RPERPB (₹) & \\
\hline 1. & Ration card & 1.69 & 287 (33.95) & $379(44.80)$ & $179(21.16)$ & $846(100)$ \\
\hline 2. & Mid-Day Meal scheme & 0.00 & $0(0.00)$ & $0(0.00)$ & $0(0.00)$ & $0(0)$ \\
\hline 3. & Yashasvini card & 2.00 & $340(43.04)$ & $350(44.30)$ & $100(12.66)$ & $790(100)$ \\
\hline 4. & Kaliyuva Makkalige bicycle & 0.00 & $0(0.00)$ & $0(0.00)$ & $0(0.00)$ & $0(0)$ \\
\hline 5. & Old age pension scheme & 10.71 & $1821(64.23)$ & $757(26.70)$ & $257(9.07)$ & $2836(100)$ \\
\hline 6. & Namma Mane & 5.00 & $850(22.08)$ & $2500(64.94)$ & $500(12.990$ & $3850(100)$ \\
\hline 7. & Bhagya laxmi yojana & 1.50 & $255(42.15)$ & $250(41.32)$ & $100(16.53)$ & $605(100)$ \\
\hline 8. & Bhagyajyothi & 1.47 & $249(38.37)$ & $247(37.96)$ & $154(23.67)$ & $650(100)$ \\
\hline 9. & Indira Awas Yojana & 3.60 & $612(15.64)$ & $2200(56.24)$ & $1100(28.12)$ & $3912(100)$ \\
\hline 10. & Bhoochetana Scheme & 3.00 & $510(56.04)$ & $267(29.30)$ & $133(14.65)$ & $910(100)$ \\
\hline 11. & Ambedkar devboard scheme & 3.00 & $510(25.37)$ & $1000(49.75)$ & $500(24.88)$ & $2010(100)$ \\
\hline 12. & Nirmala Grama & 2.07 & $352(27.65)$ & $729(57.21)$ & $193(15.14)$ & $1274(100)$ \\
\hline 13. & Widow scheme & 1.50 & $255(31.68)$ & $350(43.48)$ & $200(24.84)$ & $805(100)$ \\
\hline \multirow[t]{2}{*}{14.} & MGNREGA & 1.00 & $170(23.13)$ & $320(43.54)$ & $245(33.33)$ & $735(100)$ \\
\hline & Average value & 3.05 & $518(32.32)$ & $779(48.63)$ & $305(19.05)$ & $1602(100)$ \\
\hline
\end{tabular}

TSAB: Time spent in availing the benefit (Man days); OCLAB: Opportunity cost of labour in availing the benefit (₹); EMODPAC; Expenditure made in obtaining documents plus associated cost (₹); RPERPB: Rent paid exclusively for receiving program benefit $(₹)$; Figures in parentheses represent percentage to total

Table 5: Transaction costs incurred by non- migration agricultural labour households in availing benefit of developmental programs in irrigated situation

\begin{tabular}{|c|c|c|c|c|c|c|}
\hline \multirow{2}{*}{$\begin{array}{l}\text { Sl. } \\
\text { No. }\end{array}$} & \multirow{2}{*}{$\begin{array}{l}\text { Name of the program / } \\
\text { scheme }\end{array}$} & \multirow[t]{2}{*}{ TSAB } & \multicolumn{3}{|c|}{ Transaction cost } & \multirow{2}{*}{$\begin{array}{l}\text { Total transaction } \\
\text { cost program } \text { p }^{-1}\end{array}$} \\
\hline & & & OCLAB (₹) & EMODPAC (₹) & RPERPB (₹) & \\
\hline 1. & Ration card & 2.07 & $351(40.09)$ & $347(39.56)$ & $178(20.35)$ & $876(100)$ \\
\hline 2. & Mid-Day Meal scheme & 0.00 & 0(0.000 & $0(0.00)$ & $0(0.00)$ & $0(0.00)$ \\
\hline 3. & Yashasvini card & 2.00 & $340(45.95)$ & $300(40.54)$ & $100(13.51)$ & $740(100)$ \\
\hline 4. & Kaliyuva Makkalige bicycle & 0.00 & $0(0.00)$ & $0(0.00)$ & $0(0.00)$ & 0(0.00 \\
\hline 5. & Old age pension scheme & 2.27 & $386(31.14)$ & $609(49.08)$ & 245(19.78) & $1241(100)$ \\
\hline 6. & Namma Mane & 0.00 & $0(0.00)$ & $0(0.00)$ & $0(0.00)$ & $0(0.00$ \\
\hline 7. & Bhagya laxmi yojana & 2.33 & $397(36.17)$ & $500(45.59)$ & $200(18.24)$ & $1097(100)$ \\
\hline 8. & Bhagyajyothi & 1.21 & $206(40.20)$ & $200(38.94)$ & $107(20.86)$ & $514(100)$ \\
\hline 9. & Indira Awas Yojana & 3.67 & $623(34.82)$ & $667(37.24)$ & $500(27.93)$ & $1790(100)$ \\
\hline 10. & Bhoochetana Scheme & 1.80 & $306(41.58)$ & $280(38.04)$ & $150(20.38)$ & $736(100)$ \\
\hline 11. & $\begin{array}{l}\text { Ambedkar devboard } \\
\text { scheme }\end{array}$ & 7.00 & 119024.09) & $1750(35.43)$ & $2000(40.49)$ & $4940(100)$ \\
\hline 12. & Nirmala Grama & 2.11 & $359(38.32)$ & $378(40.33)$ & $200(21.35)$ & $937(100)$ \\
\hline 13. & Widow scheme & 3.60 & $612(45.27)$ & $500(36.98)$ & $240(17.75)$ & $1352(100)$ \\
\hline \multirow[t]{2}{*}{14.} & MGNREGA & 1.67 & $283(32.69)$ & $350(40.38)$ & $233(26.92)$ & $867(100)$ \\
\hline & Average value & 2.70 & $459(40.56)$ & $535(47.18)$ & $378(33.34)$ & $1133(100)$ \\
\hline
\end{tabular}

Figures in parentheses represent percentage to total

highest transaction cost of ₹ 8333 family $^{-1}$ was incurred while getting benefit from the Namma Mane of which $60 \%$ was the rent paid, $28.00 \%$ was the documentation and remaining $12 \%$ was the opportunity cost of labour ( 5 man days). Similarly, 


\begin{tabular}{|c|c|c|c|c|c|c|}
\hline \multirow{2}{*}{$\begin{array}{l}\text { Sl. } \\
\text { No. }\end{array}$} & \multirow[t]{2}{*}{ Name of the program/scheme } & \multirow[t]{2}{*}{ TSAB } & \multicolumn{3}{|c|}{ Transaction cost } & \multirow{2}{*}{$\begin{array}{l}\text { Total transaction } \\
\text { cost program }{ }^{-1}(₹)\end{array}$} \\
\hline & & & OCLAB (₹) & EMODPAC (₹) & RPERPB (₹) & \\
\hline 1. & Ration card & 2 & $453(42.36)$ & $342(32.02)$ & $273(25.62)$ & $1068(100)$ \\
\hline 2. & Mid-Day Meal scheme & 0 & $0(0.00)$ & $0(0.00)$ & $0(0.00)$ & $0(0.00)$ \\
\hline 3. & Yashasvini card & 0 & $0(0.00)$ & $0(0.00)$ & $0(0.00)$ & $0(0.00)$ \\
\hline 4. & Kaliyuva Makkalige bicycle & 0 & $0(0.00)$ & $0(0.00)$ & $0(0.00)$ & $0(0.00)$ \\
\hline 5. & Old age pension scheme & 3 & $600(37.50)$ & $500(31.25)$ & $500(31.25)$ & $1600(100)$ \\
\hline 6. & Namma Mane & 5 & $1000(12.00)$ & $2333(28.00)$ & $5000(60.00)$ & $8333(100)$ \\
\hline 7. & Bhagya laxmi yojana & 0 & $0(0.00)$ & $0(0.00)$ & $0(0.00)$ & $0(0.00)$ \\
\hline 8. & Bhagyajyothi & 2 & $360(35.36)$ & $400(39.29)$ & $258(25.34)$ & $1018(100)$ \\
\hline 9. & Indira Awas Yojana & 5 & $1000(20.00)$ & $2000(40.00)$ & $2000(40.00)$ & $5000(100)$ \\
\hline 10. & Bhoochetana Scheme & 0 & $0(0.00)$ & $0(0.00)$ & $0(0.00)$ & $0(0.00)$ \\
\hline 11. & Ambedkar devboard scheme & 4 & $700(21.88)$ & $1250(39.06)$ & $1250(39.06)$ & $3200(100)$ \\
\hline 12. & Nirmala Grama & 0 & $0(0.00)$ & $0(0.00)$ & $0(0.00)$ & $0(0.00)$ \\
\hline 13. & Widow scheme & 2 & $420(32.66)$ & $480(37.33)$ & $386(30.02)$ & $1286(100)$ \\
\hline \multirow[t]{2}{*}{14.} & MGNREGA & 0 & $0(0.00)$ & $0(0.00)$ & $0(0.00)$ & $0(0.00)$ \\
\hline & Average value & 2 & $324(21.08)$ & $521(33.97)$ & $690(44.95)$ & $1536(100)$ \\
\hline
\end{tabular}

Note: Figures in parentheses represent percentage to total

Table 7: Transaction costs incurred by non-migration agricultural labour households in availing benefit of developmental programs in rainfed situation

\begin{tabular}{|c|c|c|c|c|c|c|}
\hline \multirow{2}{*}{$\begin{array}{l}\text { Sl. } \\
\text { No. }\end{array}$} & \multirow{2}{*}{$\begin{array}{l}\text { Name of the program/ } \\
\text { scheme }\end{array}$} & \multirow[t]{2}{*}{ TSAB } & \multicolumn{3}{|c|}{ Transaction cost } & \multirow{2}{*}{$\begin{array}{l}\text { Total transaction } \\
\text { cost program }{ }^{-1}(₹)\end{array}$} \\
\hline & & & OCLAB (₹) & EMODPAC (₹) & RPERPB (₹) & \\
\hline 1. & Ration card & 3 & $517(38.96)$ & $466(35.07)$ & $345(25.97)$ & $1328(100)$ \\
\hline 2. & Mid-Day Meal scheme & 0 & $0(0.00)$ & $0(0.00)$ & $0(0.00)$ & $0(0.00)$ \\
\hline 3. & Yashasvini card & 3 & $600(40.00)$ & $500(33.33)$ & $400(26.67)$ & $1500(100)$ \\
\hline 4. & Kaliyuva Makkalige bicycle & 0 & $0(0.00)$ & $0(0.00)$ & $0(0.00)$ & $0(0.00)$ \\
\hline 5. & Old age pension scheme & 2 & $400(34.15)$ & $386(32.93)$ & $386(32.93)$ & $1171(100)$ \\
\hline 6. & Namma Mane & 5 & $1000(11.11)$ & $5000(55.56)$ & $3000(33.33)$ & $9000(100)$ \\
\hline 7. & Bhagya laxmi yojana & 0 & $0(0.00)$ & $0(0.00)$ & $0(0.00)$ & $0(0.00)$ \\
\hline 8. & Bhagyajyothi & 2 & $400(34.78)$ & $400(34.78)$ & $350(30.43)$ & $1150(100)$ \\
\hline 9. & Indira Awas Yojana & 3 & $733(14.47)$ & $1333(26.32)$ & $3000(59.21)$ & $5067(100)$ \\
\hline 10. & Bhoochetana Scheme & 0 & $0(0.00)$ & $0(0.00)$ & $0(0.00)$ & $0(0.00)$ \\
\hline 11. & Ambedkar devboard scheme & 0 & $0(0.00)$ & $0(0.00)$ & $0(0.00)$ & $0(0.00)$ \\
\hline 12. & Nirmala Grama & 0 & $0(0.00)$ & $0(0.00)$ & $0(0.00)$ & $0(0.00)$ \\
\hline 13. & Widow scheme & 0 & $0(0.00)$ & $0(0.00)$ & $0(0.00)$ & $0(0.00)$ \\
\hline \multirow[t]{2}{*}{14.} & MGNREGA & 0 & $0(0.00)$ & $0(0.00)$ & $0(0.00)$ & $0(0.00)$ \\
\hline & Average value & 3.04 & $608(19.00)$ & $1347(42.07)$ & $1247(38.93)$ & $3203(100)$ \\
\hline
\end{tabular}

Note: Figures in parentheses represent percentage to total

₹ 5,000 family ${ }^{-1}$ was incurred for getting benefit from Indira Awas Yojana of which $40 \%$ was the rent paid, $20 \%$ was the opportunity cost of labour ( 5 man days) and $40.00 \%$ was documentation cost. 
For the widow pension scheme, labour households incurred transaction cost of ₹ 1,286 of which $30.66 \%$ was opportunity cost of labor, $30.02 \%$ was the rent and $37.33 \%$ was documentation cost.

In case of non-migration labour households, highest transaction cost of ₹ 9,000 family ${ }^{-1}$ was incurred for getting benefit from the namma mane of which $33.33 \%$ was the rent paid, $56 \%$ was the documentation and remaining $11 \%$ was the opportunity cost of labour (5 man days). Similarly for Indira Awas Yojana, ₹ 5,067 family ${ }^{-1}$ was incurred for getting benefit, out of which $59.21 \%$ was the rent paid, $14.47 \%$ was the opportunity cost of labour ( 3 man days) and $26.32 \%$ was documentation cost. For getting benefit from the ration card, labour households incurred transaction cost of ₹ 1,327 of which $38.96 \%$ was opportunity cost of labor, $25.97 \%$ was the rent and $35.07 \%$ was documentation cost.

The transaction cost for getting benefit was zero in programmes like Mid-Day Meal and Kaliyuva Makkalige Bicycle which is free of any rent. Opportunity cost was worked out on the basis of the next best alternative available to the person (i.e. daily wage rate of work @ ₹ 2,00 man ${ }^{-1}$ day) instead of spending time on availing benefit.

\section{Conclusion}

Education has multidimensional impact not only on enhancing knowledge but also the efficiency and overall livelihood security of household. Hence, government should evolve a special package to increase literacy level of labourers children to reduce school drop outs. Besides existing incentives, additional incentives may be provided for higher education. The programmes already undertaken by government have greater implications on labour and thus are to be pursued further with more vigor to strengthen the household food security.

\section{References}

Bhuvaneshwari, P. C., 2008, Livelihood analysis for rural poor.
Proceedings of International Symposium on Strategies for Improving Livelihood Security of Rural Poor. Old Goa, India, 241-243.

Devi Sivasakthi, T., Balasubramanian, R., Ganeshkumar, B., 2011. Employment, income and labour supply decision of rural households: An economic analysis of MGNREGS in Tamil Nadu. Agricultural Economics Research Review, 24, 473-484.

Harisha, B.G., Nagaraj, N., Chandrakantha, M.G., Srikanthamurthy, P.S., Chengappa, P.G., Basavaraj, G., 2011. Impacts and implications of MGNREGA on labour supply and income generation for agriculture in Central Dry Zone of Karnataka. Agricultural Economics Research Review 24, 485-494.

Maheshwari, S., Gangwar, L.S., 2011, Impact of rural development scheme on availability of agricultural labour- a study of dairy farmers in Thanjavur district of Tamil Nadu. Agricultural Economics Research Review 24(1), 409-414.

Merin, S., Thadathil and Vineeth, Mohandas, 2012, Impact of MGNREGS on labour supply to agricultural sector of Wayanad district in Kerala. Agricultural Economics Research Review 25(1), 151-155.

Prabakara, C., Sita, K., Selvamb, S., 2011, Labour scarcityits immensity and impact on agriculture. Agricultural Economics Research Review 24(1), 373-380.

Salim, S.S., Sathiadhas, R., Narayanakumar, R., Katiha, P.K., Krishnan, M., Biradar, R.S., Nikitagopal., Nageshbarik and Ganeshkumar, B., 2013, Rural livelihood security: assessment of fishers' social status in India. Agricultural Economics Research Review 26, 21-30.

Upadhyay, R.P., Palanivel, C., 2011. Challenges in achieving food security in India. Iranian Journal of Public Health 40(4), 31-36. 